\title{
鉄骨柱材の耐力特性 STRENGTH CHARACTERISTICS OF STEEL BEAM-COLUMNS
}

\author{
中島正愛*, 森野捷輔**, 古場 覚司*** \\ Masayoshi NAKASHIMA, Shosuke MORINO and Satoshi KOBA
}

\begin{abstract}
Strength characteristics of steel beam-columns are discussed by statistically evaluating the data obtained from previous experimental studies. A total of 237 test data are selected in this study, and their individual properties like material and geometrical properties and maximum resistances are stored in a computer in the format of a relational data base.

Strength of the test data (designated as the experimental strength) is calibrated against the strength assumed in the strength provisions of the LSD Specification (designated as the predicted strength), and following observations are made.

(1) The experimental strength is $15 \%$ larger on the average than the predicted strength.

(2) The experimental strength relative to the predicted strength is larger for beam-columns with moment-gradient than for those with uniform-moment, and it occurs most likely because the effect of strain hardening on the strength is not included in the predicted strength.

(3) If the nominal yield stress is used instead of the real yield stress, the difference between the experimental and predicted strengths is expanded further by $7 \%$.

(4) The experimental strength is $36 \%$ larger on the average than the design strength stipulated in the LSD Specification.

(5) The primary source that have produced the difference between the experimental and design strengths is not the variation of yield stress but the error involved in the predicted strength.
\end{abstract}

Keywords : beam-columns, strength, database, design, provisions

\section{1.はじめに}

安全で合理的な構造設計を実現するうえで, 構造設計 規準の果たす役割は大きい。より高度な構造設計を目指 して, 新しい概念や規定を構造設計規準に組み込み，ま た既往の規定を修正するための努力は続いている。設計 規定を新たに定めたり，既往の規定を修正したりするに あたってなすべきことの一つとして，その規定が対象と している構造性能に関する既往の研究成果を分析するこ とによって,

・構造性能を左右する因子を適切に抽出すること ・これら因子の構造性能に対する影響度を正しく評価す ること

が挙げられる。そして, 影響度の高い因子に対しては, この影響が正しく反映されるように規定を整備し,一方, 二次的と判断された因子に対しては，規定にある程度余 裕度を持たせることと引き換えに，これを規定の拘束か ら排除することによって，十分な精度と安全性を保ちな がらしかも簡潔で使いやすい規定を作ることができる。
昨今, 構造部材・要素個々の性能を調べた研究の数が あまりにも多くなった結果，これらの研究成果に対する 横断的な分析が追いつかず, その結果として, 研究成果 の多くが規定に正しく反映されていないのではないかと いう懸念は少なくない。本研究の目的は, 設計規定を適 切に整備するうえで必要な知識を，それに関連する数多 くの研究を横断的に分析することを通じて提示しようと するものである。本論文では，対象とする設計規定とし て，曲げと軸圧縮力を同時に受ける鉄骨柱材の耐力規定 を採り上げた。また分析すべき研究成果として，過去 20 年間に日本で行われた, 鉄骨柱材に対する実験的研 究を用いた。これら実験結果を, 現実の柱材の挙動を再 現したものととらえ，各実験で課せられた条件に従って 分類することによって，柱材の耐力に及ぼす各因子の影 響度を定量化するとともに, 同定することが難しい不確 定な因子によって生じる，いわゆる「ばらつき」をも積 極的に評価することにした。このようなばらつきを定量 化することは，近年の趨勢である信頼性に立脚した設計
* 神戸大学 助教授 $\cdot$ Ph. D.

**三重大学 教授・工博

*** 神戸大学 大学院
Associate Professor, Kobe Univ., Ph. D.

Professor, Mie Univ., Dr. Eng.

Graduate Student, Kobe Univ. 
体系（例えば，鋼構造限界状態設計規準案（1990）（以 下 LSD 規準（案）と称す）が求めるところにも一致す る。

\section{2. 柱の設計式と実験データ}

\section{1 柱の設計式}

LSD 規準（案）では柱の曲げ圧縮限界耐力として， 曲げ面内限界状態と曲げ面外限界状態それぞれに，以下 の規定を設けている。

$$
\begin{aligned}
& \frac{N}{\phi_{c} N_{c x}}=1.0 \\
& \frac{N}{\phi_{p} N_{y}}+0.85 \psi \frac{M}{\phi_{p} M_{p}}=1.0 \\
& \frac{M}{\phi_{b} M_{c}}=1.0 \\
& \frac{N}{\phi_{c} N_{c r}}+0.85 \frac{M}{\phi_{b} M_{c}}=1.0 \\
& M: \text { 曲げモーメント } \\
& M_{c}: \text { 横座屈限界耐力 } \\
& N ： \text { 軸圧縮力 } \\
& M_{\rho}: \text { 全塑性モーメント } \\
& N_{c x}: \text { 曲げ面内の座屈限界耐力 } \\
& N_{c Y}: \text { 曲げ面外の座屈限界耐力 } \\
& N_{y}: \text { 降伏限界耐力 } \\
& \psi \text { : 付加曲げ効果を考虑する係数（詳細は原典を参 }
\end{aligned}
$$

$\phi_{p}, \phi_{c}, \phi_{b}$ : 酎力係数

一方米国における鋼構造設計規準の一つである AISC の LRFD 規準 (1986) では, 柱の限界耐力として以下 の式を与えている。記号の詳細については原典を参照さ れたい。

$$
\begin{aligned}
& \frac{P_{u}}{\phi P_{n}} \geqq 0.2 \text { のとき } \frac{P_{u}}{\phi P_{n}}+\frac{8 M_{u}}{9 \phi_{b} M_{n}}=1.0 \cdots \cdots \cdots \text { ( } 5 \text { ) } \\
& \frac{P_{u}}{\phi P_{n}}<0.2 \text { のとき } \frac{P_{u}}{2 \phi P_{n}}+\frac{M_{u}}{\phi_{b} M_{n}}=1.0 \cdots \cdots . . .(6) \\
& M_{u}=B_{1} M_{n t}+B_{2} M_{t t} \\
& B_{1}=\frac{C_{m}}{\left(1-P_{u} / P_{e}\right)} \geqq 1.0 \\
& B_{2}=\frac{1}{1-\sum P_{u}\left(\frac{\Delta_{0 h}}{\sum H L}\right)} \\
& \phi, \phi_{b} \text { : 耐力係数 } \\
& P_{n}, M_{n} \text { : 公称耐力 } \\
& P_{u}, M_{u} \text { : 限界耐力 } \\
& C_{m}=0.6-0.4\left(M_{1} / M_{2}\right) \\
& M_{1} / M_{2} \text { : モーメント勾配 }
\end{aligned}
$$

上記の LSD 規準（案）式，LRFD 規準式に対する筆 者らの理解は以下のとおりである。これらの式はともに， いわゆる最危険断面の初期降伏に対する軸力と曲げモ一 メントの相関式が基礎になっている（この相関式を導き
出す過程においては，モーメント勾配や材の曲げたわみ による $P \delta$ 効果は考慮されているが，ひずみ硬化，残留 応力, 初期たわみ, 局部座屈等の影響は考えられていな い。)。このように求められた相関式では，座屈が引き金 となって生じる安定限界耐力を表現できないので, これ を圧縮材の曲げ座屈耐力や，梁の横座屈耐力を用いて書 き換えたものが，式（1)（6）である。この導出過程 には飛躍が見られるが，その結果として得られる設計式 は簡便であり，また実験結果と比較しても余りかけ離れ ていないという事実などから，長年にわたって採用され てきた。次節以降の議論を明確にするために，式（1） ～(6) に対する筆者らの所見を以下に示す。(1)上記設 計式中に現れる曲げ座屈耐力や横座屈耐力は実験結果な ぞも勘案して決められているので，そこには残留応力や 初期たわみの影響が含まれているが，それらは設計式の 中に陽な形では表現されていない。(2)局部座屈について は別途規定が設けられており，上記設計式には局部座屈 の影響は含まれていない。(3)ひずみ硬化による耐力の上 昇は，短い材に対する曲げ座屈耐力や横座屈耐力に考虑 されているので，上記設計式の中にもその効果が含まれ ているはずであるが，いずれにしても公称降伏応力度を 用いて計算した降伏耐力や全塑性モーメントで頭打ちと

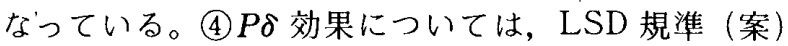

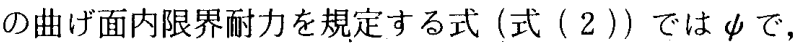
また LRFD 規準式（式（5)，(6)) では $B_{1}$ で考慮さ れている。一方, 柱頭部が柱脚部に対して横移動するこ と（サイドスウェイ）によって生じる $P \Delta$ 効果につい ては，LRFD 規準式では，式（9）に示す増幅係数を 用いることによってこれを考慮している。一方 LSD 規 準（案）では，その解説において，PA効果が大きいと 見なされる場合には，骨組解析においてこの効果を考慮 して柱の必要耐力を算定し，設計耐力式を適用すること が望ましいと記している。

\section{2 実験デー夕の調查}

過去 20 年間に日本建築学会論文報告集, 同大会学術 講演梗概集, 各支部報告集で公表された実験資料の中で, (1) H 形断面材に対して, 軸王縮力之強軸回りに曲げを作 用させた実験，(2)柱材単体としての実験（骨組に組み込 まれた実験は含まれていない)，(3)単調載荷による実験， を調査の対象とした。ただし，いわゆる繰返し載荷実験 でも, 初期載荷で明らかに最大耐力が推定できるものは 含めた。また数值解析によるデー夕は除外した。以上の 条件に適合するデータとして 19 文献, データ数にして 285 を選び出した。その中で, 軸力が 0 のものが 29 デー 夕，また素材試験加ら得られた降伏応力度（実測降伏応 力度と定義）の記述のなかったデータが 19 データあっ たので，これらを除外した。最終的に考察の対象とした 有効デー夕総数は 237 であった。実験の詳細はそれぞれ 
表一1 調查文献, 実験デー夕数, 実験条件の一覧

\begin{tabular}{|c|c|c|c|}
\hline Designation & $\begin{array}{r}\text { Number } \\
\text { of Data }\end{array}$ & $\begin{array}{l}\text { Support (*) } \\
\text { Condition }\end{array}$ & $\begin{array}{l}\text { Type of } \\
\text { Forming }\end{array}$ \\
\hline UDAGAWO1 & 5 & $1-4$ & 1 \\
\hline KATOOO01 & 18 & $1-1$ & 3 \\
\hline KATO0002 (01 03) & 3 & $3-4$ & 2 \\
\hline KATO0002 (04 07) & 4 & $4-4$ & 3 \\
\hline SUZURI 01 & 21 & $1-1$ & 1 \\
\hline SUZUKI $02(01 \sim 12)$ & 12 & $3-3$ & 1 \\
\hline SUZUKI $02(13 \sim 18)$ & 6 & $3-5$ & 2 \\
\hline SUZUKI $03(01 \sim 07)$ & 7 & $1-1$ & 1 \\
\hline SUZUKI $03(08 \sim 13)$ & 6 & $1-1$ & 2 \\
\hline SUZURI 04 & 16 & $3-3$ & 1 \\
\hline SUZUKI 05 & 6 & $3-3$ & 1 \\
\hline TANAKA01 & 7 & $1-4$ & 1 \\
\hline NARASH 01 & 14 & $1-4$ & 1 \\
\hline NAKASH 02 & 42 & $4-4$ & 1 \\
\hline FURUCHOI & 4 & $3-4$ & 2 \\
\hline FURUCHO2 & 12 & $3-4$ & 2 \\
\hline FUKUCHO3 & 12 & $3-4$ & 2 \\
\hline FURUCHO4 & 9 & $3-4$ & 2 \\
\hline FURUCH05 & 9 & $3-4$ & 2 \\
\hline MAKINOO 1 & 29 & $2-4$ & 2 \\
\hline MITANI 01 & 36 & $2-2$ & 2 \\
\hline WAKABAO 1 & 7 & $1-4$ & 1 \\
\hline
\end{tabular}

(*) First Number About Strong Axis, and Second Number

About Weak Axis (For Numbers, See Fig.1)

Type of Forming: 1:hot rolled; 2:built-up; 3: wachined

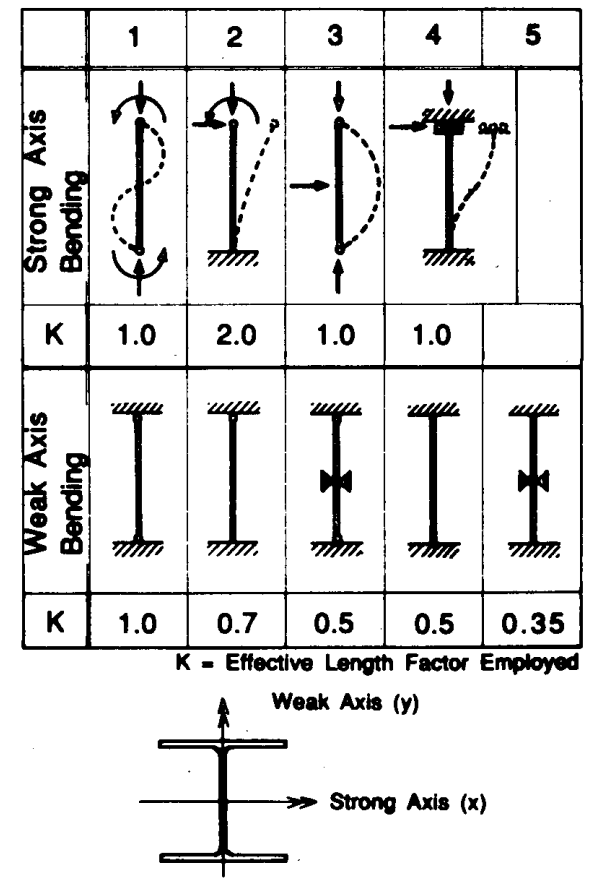

図一1 実験データの載荷支持条件

の文献を参照されたい。

表- 1 に, 各文献ごとの試験体数, 載荷・支持条件 (記 号については図一1を参照)，製作形式を示す。各試験 体ごとに, 試験体緒元, 材料特性, 載荷条件, 最大耐力 等を抽出して，これらをデータベースとしてコンピュー タの中に組み込んだ。

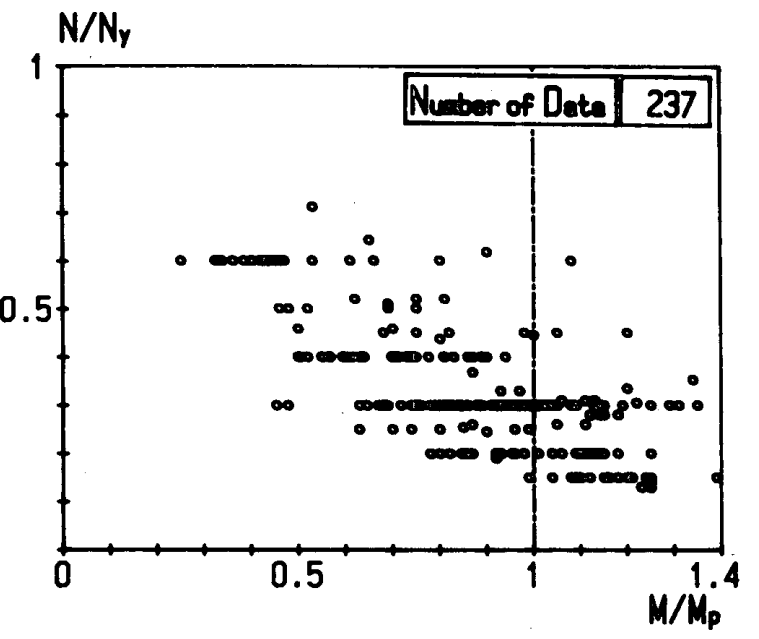

図一2 軸力と最大曲げモーメントの関係

表一2 実験データの無次元化細長比別の分類

\begin{tabular}{|c||c|}
\hline $\begin{array}{c}\text { Normalized } \\
\text { Slenderness Ratio } \\
\text { About Strong Axis }\end{array}$ & $\begin{array}{c}\text { Number } \\
\text { of } \\
\text { Data }\end{array}$ \\
\hline \hline $0.1 \leqq \overline{\lambda x}<0.2$ & 2 \\
\hline $0.2 \leqq \overline{\lambda x}<0.3$ & 76 \\
\hline $0.3 \leqq \overline{\lambda x}<0.4$ & 47 \\
\hline $0.4 \leqq \bar{x}<0.5$ & 58 \\
\hline $0.5 \leqq \sqrt{x}<0.6$ & 25 \\
\hline $0.6 \leqq \overline{\lambda x}<0.7$ & 18 \\
\hline $0.7 \leqq \overline{\lambda x}<0.8$ & 5 \\
\hline $0.8 \leqq \overline{\lambda x}<0.9$ & 6 \\
\hline Total & 237 \\
\hline
\end{tabular}

$\bar{x}=\frac{\lambda \times(\text { Slenderness Ratio about Strong Axis })}{\pi \sqrt{E / \sigma y}(\text { Yield Slenderness Ratio })}$

3. データの分析

3.1 実験データの分類

分析結果の一例として, 軸力比と最大耐力の関係を図 一2 に示す。なお図中, 縦軸, 横軸の分母である $N_{y}$ (降 伏軸力）と $M_{p}$ (全塑性モーメント) は，いずれも実測 による降伏応力度と断面寸法をもとに算定した。また最 大耐力として用いた曲げモーメントは，柱の断面に作用 する一次 (first order) の最大曲げモーメントであり, いわゆる $P \delta$ や $P \Delta$ 効果による付加的なモーメントは含 まれていない。降伏軸圧縮力で座屈するような材の細長 比 $\left(=\pi \sqrt{E / \sigma_{y}}\right.$ (降伏細長比亡定義)：ここで $E$ はヤン グ係数， $\sigma_{y}$ は実測降伏応力度）で無次元化した細長比 (LSD 規準（案）における曲げ面内の細長比： $\lambda_{c}$ に相 当）別の実験デー夕数を表一 2 に，軸力比 $\left(N / N_{y}\right)$ 別の 実験デー夕数を表一 3 に，降伏比別の実験デー夕数を表 
-4 に，材断面の幅 $(B)$ のせい $(H)$ に対する比 $(B / H)$ 別 の実験デー夕数を表一 5 に，また LSD 規準（案）によ る幅厚比区分別の実験デー夕数を表一6中段にそれぞれ 示す。 $80 \%$ 以上の実験データが無次元化細長比にして 0.5 以下で，また幅厚比も小さく(LSD 規準（案）幅 厚比区分 P-I と P-IIに属するもので $72 \%$ を占めてい る)，塑性設計を意識したと思われる実験が大半を占め ていた。また $B / H$ が 1.0 以上のデータが全体の $78 \%$ 以上を占めており，いかゆる広幅 $\mathrm{H}$ 形断面材に対する実 験が多い。降伏比別では, 降伏比が $0.6 \sim 0.8$ のデー夕 が全体の $93 \%$ を占めていた。また全データの降伏比の 平均値は 0.70 であった。

\section{2 柱材の強度特性}

得られた実験データに基づいて，鉄骨柱材の耐力特性 を考察することにした。またこのために, LSD 規準 (案) の面外限界耐力式（式（3)，(4)) を規準値として用 いることにした。これは，H形断面材の強軸回りに曲げ が作用された実験データだけを今回の調査対象としたか らである。規準值の算定にあたっては, 耐力係数 $\left(\phi_{b}\right.$, $\left.\phi_{c}\right)$ を省くこととした。また $M_{c}, N_{c r}$ の值については, LSD 規準（案）が定めるところに従って求め, さらに これら諸量を計算するために必要な降伏強さ $\left(F_{y}\right)$ には 実測降伏応力度を，また断面量についても実測されたも のをそれぞれ用いた。そして，このようにして求めた式 (3)，（4）が，LSD 規準（案）が想定する，曲げと 軸圧縮力を同時に受ける材の耐力の予測値と仮定した。 これらの式（予測耐力式と定義）によって定められる耐 力值を予測耐力と名付け，この予測耐力と実験から得ら れた耐力（実験耐力と称す）の違いを，曲げと軸圧縮力 を同時に受ける材の耐力特性を評価するための指標とし た。またこの違いを図一 3 に示すように，実験耐力 $\left(N_{\text {exp }}, M_{\text {exp }}\right)$ の予測耐力 $\left(N_{\text {pre }}, M_{\text {ore }}\right)$ に対する比 $(R$ : 超 過比）として定義した。この定義に従うと， $N_{\text {exp }} / N_{p r e}$
表一4 実験に用いた材料の降伏比別の分類

\begin{tabular}{|c||c|r|}
\hline Vield Stress & Class & $\begin{array}{c}\text { Number } \\
\text { of Data }\end{array}$ \\
\hline \hline $0.5 \leqq \sigma y / \sigma u<0.55$ & I & 3 \\
\hline $0.55 \leqq \sigma y / \sigma u<0.6$ & I & 6 \\
\hline $0.6 \leqq \sigma y / \sigma u<0.65$ & II & 20 \\
\hline $0.65 \leqq \sigma y / \sigma u<0.7$ & II & 50 \\
\hline $0.7 \leqq \sigma y / \sigma u<0.75$ & II & 54 \\
\hline $0.75 \leqq \sigma y / \sigma u<0.8$ & III & 41 \\
\hline $0.8 \leqq \sigma y / \sigma u<0.85$ & IV & 4 \\
\hline $0.85 \leqq \sigma y / \sigma u<0.9$ & IV & 2 \\
\hline \hline Total & & 180 \\
\hline
\end{tabular}

表—5 実験データの断面特性 (H 形 断面の幅のせいに対する比)

\begin{tabular}{|c|r|}
\hline \multicolumn{1}{|c||}{$\mathrm{B}$ (Width) } & $\begin{array}{c}\text { Number } \\
\text { of } \\
\text { Data }\end{array}$ \\
\hline \hline $\mathrm{B} / \mathrm{H}<0.5$ & 6 \\
\hline $0.5 \leqq \mathrm{~B} / \mathrm{H}<0.6$ & 28 \\
\hline $0.6 \leqq \mathrm{~B} / \mathrm{H}<0.7$ & 17 \\
\hline $0.7 \leqq \mathrm{~B} / \mathrm{H}<0.8$ & 2 \\
\hline $0.8 \leqq \mathrm{~B} / \mathrm{H}<0.9$ & 0 \\
\hline $0.9 \leqq \mathrm{~B} / \mathrm{H}<1.0$ & 10 \\
\hline $1.0 \leqq \mathrm{~B} / \mathrm{H}<1.1$ & 151 \\
\hline $1.1 \leqq \mathrm{~B} / \mathrm{H}<1.2$ & 6 \\
\hline $1.2 \leqq \mathrm{~B} / \mathrm{H}<1.3$ & 5 \\
\hline $1.3 \leqq \mathrm{~B} / \mathrm{H}<1.4$ & 6 \\
\hline $1.4 \leqq \mathrm{~B} / \mathrm{H}<1.5$ & 0 \\
\hline $1.5 \leqq \mathrm{~B} / \mathrm{H}<1.6$ & 6 \\
\hline \hline Total & 237 \\
\hline
\end{tabular}

表一6 実験データの分析結果（超過比の特性） (実測降伏応力度を用いた場合)
表一3 実験デー夕の軸力比別の分類

\begin{tabular}{|c||c|}
\hline Axial Force & $\begin{array}{c}\text { Number } \\
\text { of Data }\end{array}$ \\
\hline $0<\mathrm{N} / \mathrm{N} y<0.15$ & 4 \\
\hline $0.15 \leqq \mathrm{~N} / \mathrm{N} \mathrm{y}<0.25$ & 59 \\
\hline $0.25 \leqq \mathrm{~N} / \mathrm{N} y<0.35$ & 99 \\
\hline $0.35 \leqq \mathrm{~N} / \mathrm{N} \mathrm{y}<0.45$ & 39 \\
\hline $0.45 \leqq N / N y<0.55$ & 11 \\
\hline $0.55 \leqq N / N y<0.65$ & 24 \\
\hline $0.65 \leqq \mathrm{~N} / \mathrm{Ny}$ & 1 \\
\hline Total & 237 \\
\hline
\end{tabular}

\begin{tabular}{|c|c|c|c|c|c|c|c|c|c|}
\hline \multicolumn{2}{|c|}{ Classification } & $\mathrm{n}$ & $\mathbf{a}$ & $\mathrm{b}$ & c & $\mathrm{d}$ & $\mathrm{m}$ & $\bar{\sigma}$ & $\sigma / \mathrm{m}$ \\
\hline \multicolumn{2}{|c|}{ All Data } & 237 & 0.12 & 1.10 & -.04 & 1.16 & 1.15 & 0.13 & 0.11 \\
\hline \multirow{6}{*}{$\begin{array}{l}\text { Moment } \\
\text { Gradient }\end{array}$} & o.c. & 18 & 0.18 & 1.16 & 0.30 & 1.17 & 1.25 & 0.07 & 0.06 \\
\hline & U.M. & 33 & 0.45 & 0.91 & -.06 & 1.14 & 1.12 & 0.14 & 0.13 \\
\hline & M.E. & 21 & 0.51 & 0.98 & -.29 & 1.35 & 1.25 & 0.13 & 0.10 \\
\hline & C.L. & 25 & 0.71 & 0.84 & -.06 & 1.16 & 1.14 & 0.12 & 0.11 \\
\hline & T.L. & 86 & -.01 & 1.15 & $\cdot .07$ & 1.17 & 1.15 & 0.08 & 0.07 \\
\hline & S.S. & 54 & -.70 & 1.39 & 0.13 & 1.03 & 1.08 & 0.16 & 0.15 \\
\hline \multirow{4}{*}{ 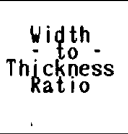 } & Class $(P-I)$ & 159 & 0.06 & 1.11 & -.04 & 1.15 & 1.13 & 0.14 & 0.12 \\
\hline & $\operatorname{class}(P-I)$ & 11 & -.11 & 1.23 & 0.16 & 1.15 & 1.20 & 0.05 & 0.04 \\
\hline & Class $(P-$ III $)$ & 17 & -.05 & 1.20 & -.01 & 1.18 & 1.18 & 0.04 & 0.04 \\
\hline & Class $(P-\mathbf{V})$ & 50 & 0.51 & 0.95 & 0.02 & 1.15 & 1.16 & 0.13 & 0.11 \\
\hline \multirow{4}{*}{$\begin{array}{l}\text { Yield } \\
\text { Ratio }\end{array}$} & Class (1) & 9 & -.61 & 1.34 & 0.32 & 0.98 & 1.10 & 0.15 & 0.14 \\
\hline & Class (II) & 70 & 0.32 & 1.06 & 0.10 & 1.18 & 1.21 & 0.14 & 0.11 \\
\hline & Class(III) & 95 & -.42 & 1.24 & 0.01 & 1.08 & 1.08 & 0.11 & 0.11 \\
\hline & Class(IV) & 6 & 1.05 & 0.60 & 0.00 & 1.15 & 1.15 & 0.18 & 0.16 \\
\hline \multirow{2}{*}{\multicolumn{10}{|c|}{$\begin{array}{l}\mathbf{n}: N \\
\mathbf{a}, b, c, d:\end{array}$}} \\
\hline & & & & & & & & & \\
\hline \multirow{2}{*}{\multicolumn{10}{|c|}{$R=a \bar{\lambda} x+b ; \quad R=c(N / N y)+d$}} \\
\hline . & \multicolumn{6}{|c|}{ Standard Deviation } & & & \\
\hline
\end{tabular}




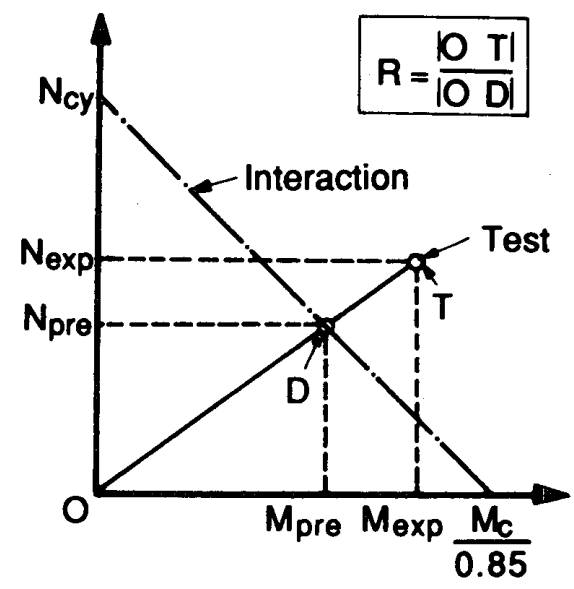

図一3 超過比の定義
$=M_{\text {exp }} / M_{p r e}=R$ が成立するので, 超過比 $(R)$ は, 実験 耐力を式（4）（ただし耐力係数は省く）に代入したと きの左辺の值を示すことになる。

3.3 LSD 規準式の部材耐力予測の精度

前節で定義した超過比を用いて実験データを分析し た。その結果を図一 4 と表一6に示す。ここで図一4(a) は軸力比と最大曲げモーメントの相関図であり, 図中の 一点鎖線は予測酎力式 (式 (4)) を示す。また図一4(b) は超過比の実験デー夕数との関係, 図一-4(c), (d) は超 過比之無次元化細長比，軸力比の関係をそれぞれ表す。 超過比の平均值は 1.15 , またその変動係数は 0.11 で あった。図一4(c)，(d) の破線は，直線回㷌式を意味す る。図一4(c) から，細長比が大きくなるほよ゙，予測耐

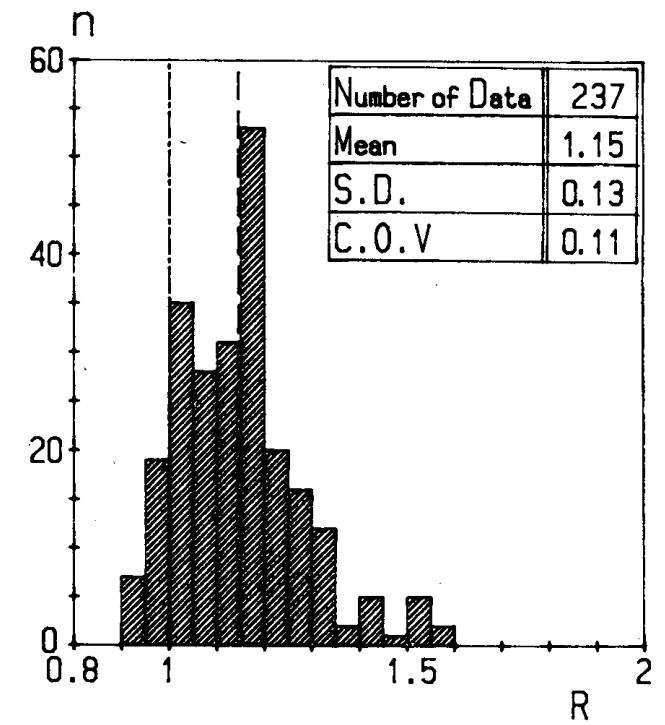

(b)

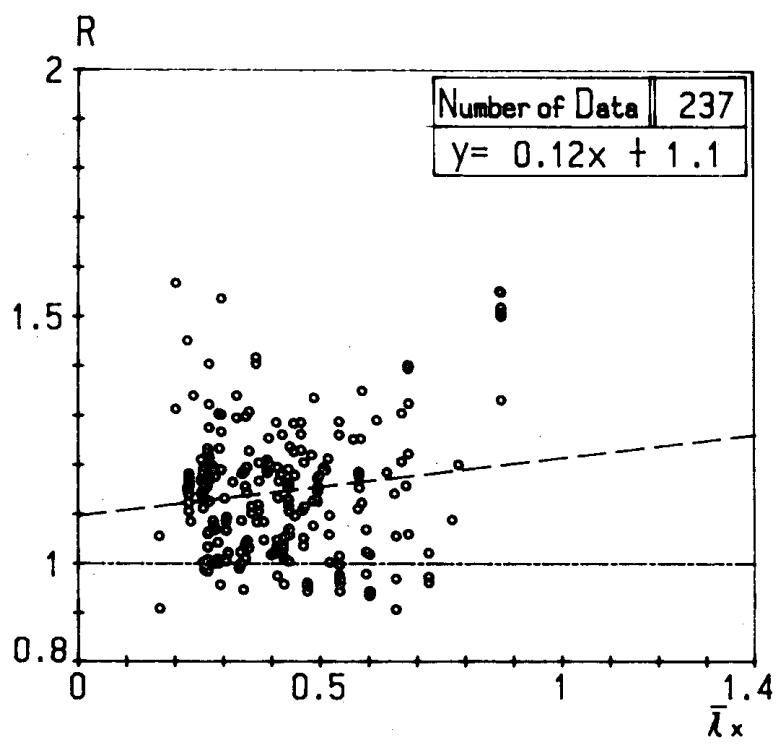

(c)

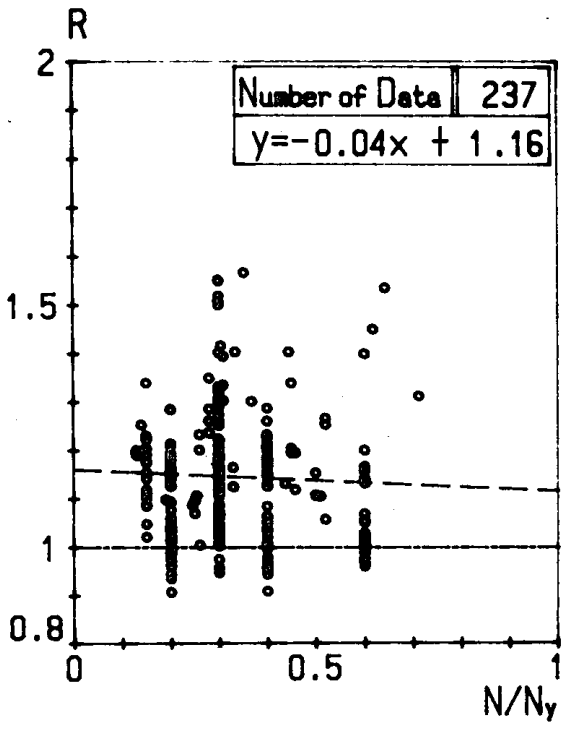

(d)

（b）超過比の頻度分布

（d）超過比之軸力比の相関

（a）軸力と最大曲げモ一メントの相関

（c）超過比と無次元化細長比の相関

図一4 実験耐力と予測耐力の比較（実測降伏応力度を用いた場合） 
力がより安全側（回帰式が右上がり）になることが分か る。細長比が大きくなるほど予測耐力式中の分母である $N_{c r}, M_{c}$ は共に小さくなるが，この減少を予測耐力式は 大きく見積り過ぎているものと解釈できる。一方軸力比

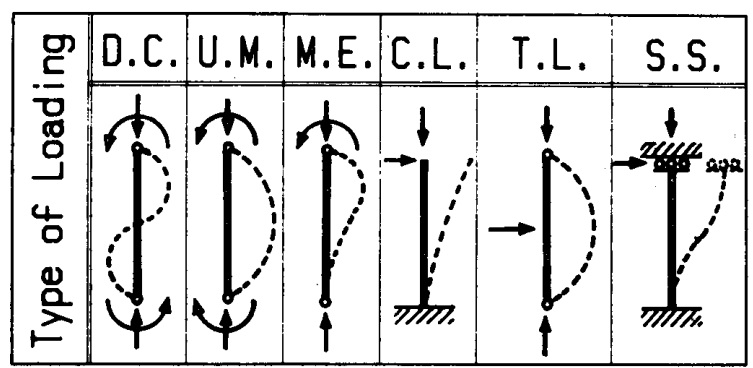

図一5 実験データの曲げモーメントによる分類

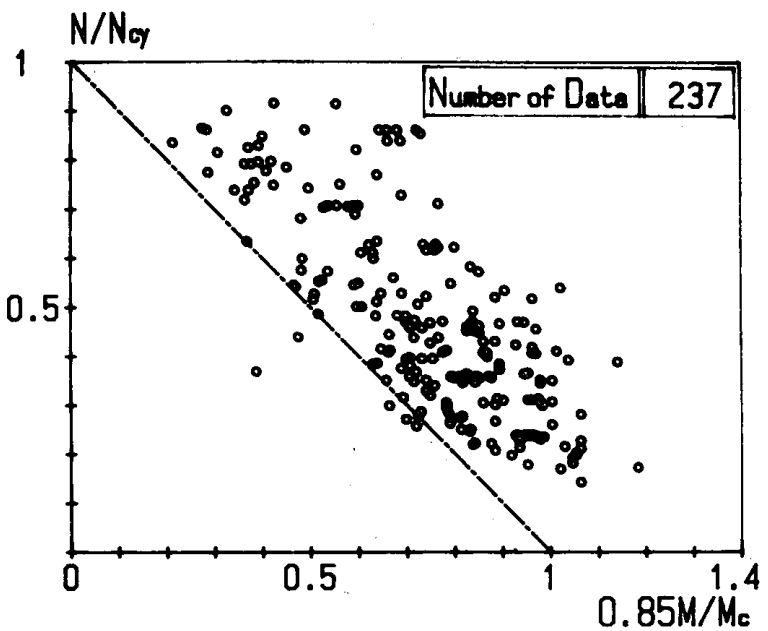

(a)

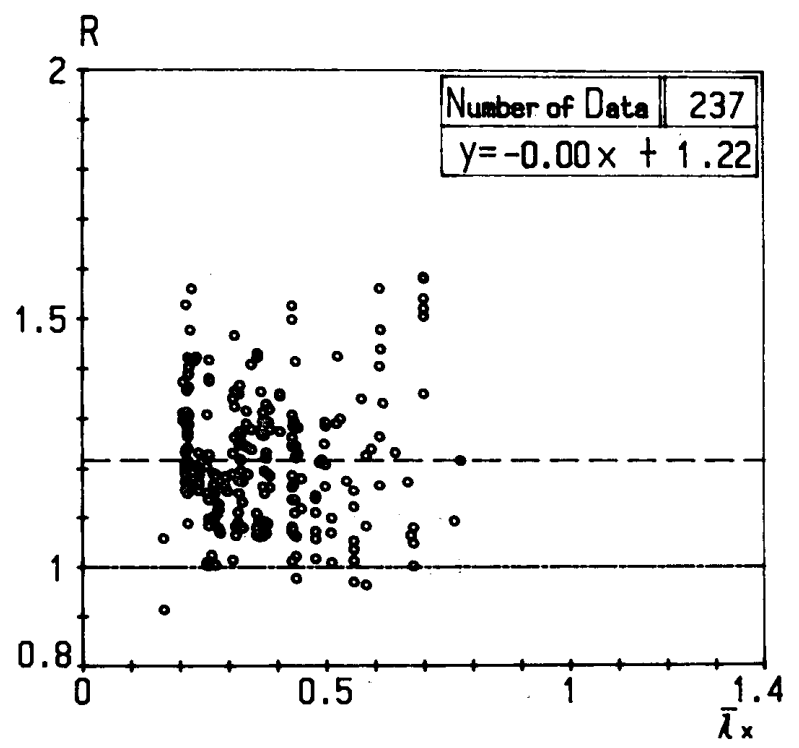

(c)

(a) 軸力と最大曲げモーメントの相関

(c) 超過比亡無次元化細長比の相関

図一6 実験耐力と予測耐力の比較（公称降伏応力度を用いた場合）
に対する直線回帰式はほぼ水平であった。

次に，載荷条件によって耐力特性がどのように変動す るかを調べるため，図一 5 に示す 6 つの載荷条件ごとに 超過比を求めた。その結果の一覧を表一6に示す。主な 結果を以下にまとめる。(1)等モーメントを受ける材の超 過比 $(R=1.12)$ が, 一端モーメントを受ける材 $(R=$ $1.25)$ や逆対称モーメントを受ける材 $(R=1.25)$ よりも 小さい。等モーメントを受ける材に比べると, 一端モ一 メントや逆対称モーメントを受ける材の方が，ひずみ硬 化を受けやすく，したがって高い耐力が期待できるが， 予測耐力式はこの効果を十分に考慮できていないこと, また等モーメントを受ける材の方が， $P \delta$ 効果による付 加曲げモーメントが大きくなるが予測耐力式にはこの効

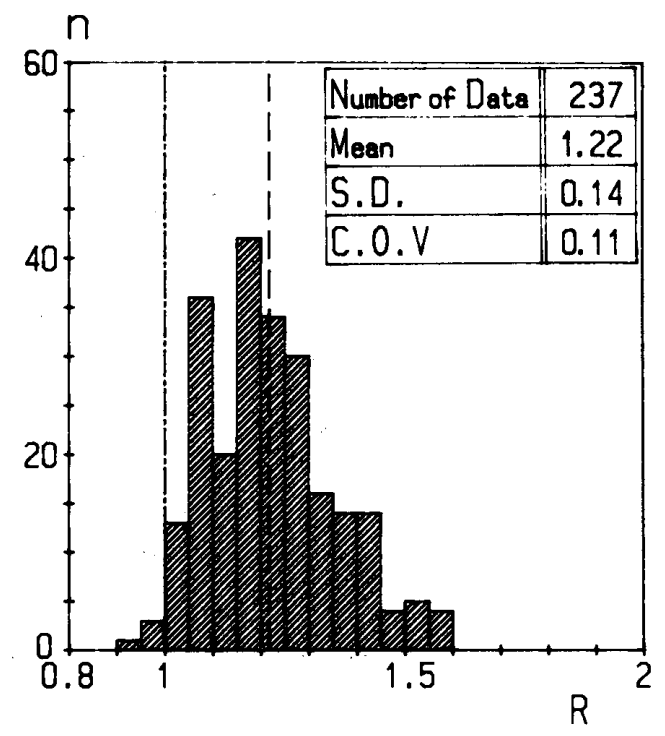

(b)

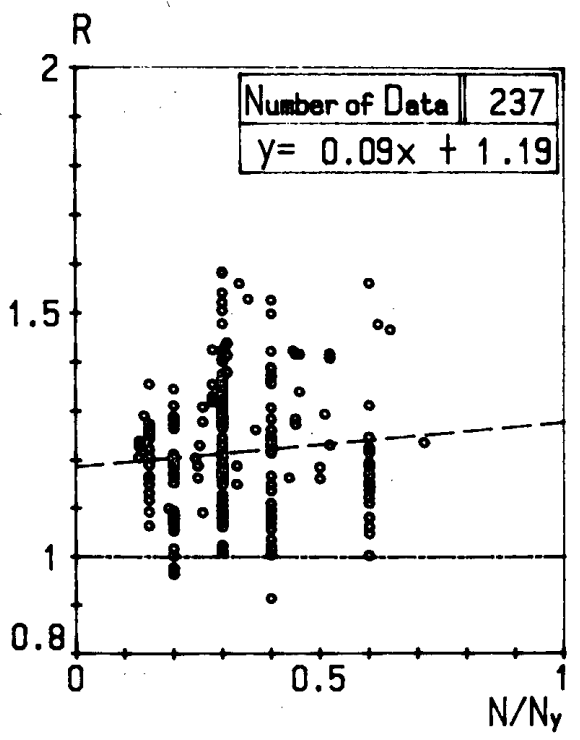

(d)

（b）超過比の頻度分布

（d）超過比と軸力比の相関 
果が含まれていないこと, 等が理由と考えられる。(2)サ イドスウェイを伴う材 $(R=1.08)$ に対する超過比が比 較的小さい。なおここで, サイドスウェイを伴う材の最 大曲げモーメント (式 $(4))$ の左辺第 2 項分子の $M$ に相当）としては, 最大水平力に材長の $1 / 2$ を乗じた值 を用いた。サイドスウェイを伴う材の超過比が小さく なった理由としては，材の柱頭が柱脚に対して変位する ことによって生じる $P \Delta$ 効果による付加モーメントを, 最大モーメントに加算しなかったことが考えられる。(3) 片持与柱 $(R=1.14)$ と集中荷重を受ける材 $(R=1.15)$ については, 面内挙動だけを考えれば基本的にはサイド スウェイを伴う材と同じ載荷条件であるが，これらの超 過比はサイドスウェイを伴う材に比べると高い。中央に 集中荷重を受ける材や片持ち柱では, 材端のほかに荷重 の載荷点において, 曲げ面外方向の移動が拘束されてい たのに対し，サイドスウェイを伴う柱では材中央におい て面外に自由に変形できた。この面外方向への拘束の有 無が, サイドスウェイを伴う柱の耐力を相対的に低くし た原因の一つであると考えられる。(4)載荷条件別の超過 比の変動係数については, 実験デー夕数がそれぞれ異な るものの，0.06〜0.15にばらついていた。

実験デー夕を，LSD 規準（案）が規定する4つの幅 厚比別に分類し，それぞれの分類ごとに超過比を求めた。 その結果も表一 6 中段に示す。幅厚比を算定するときに 必要な降伏強さとしても, 実測降伏応力度を用いた。区 分I（最も幅厚比の小さな断面を持つグループ）に分類 される実験データが全体の約 $70 \%$ を占めていた。区分 II ～IVに含まれるデータは区分 Iに比べると少ないもの の, その超過比が区分 Iにおける超過比よりも小さくな るとは限らず, 幅厚比が大きい材（特に幅厚比区分 IV の 材）では, 局部座屈の発生・成長によって耐力が早期に 失われるという，一般的な理解に反する結果となった。 この最大の理由として, 区分 Iには超過比の比較的小さ かった等モーメントを受ける材とサイドスウェイを伴う 材に対するデータが多く含まれていた（55％)のに対し，

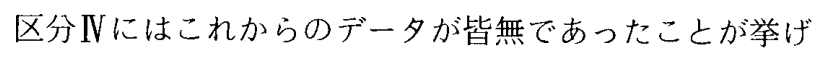
られ，局部座屈による耐力低下がひずみ硬化による耐力

表一7 実験データの分析結果（超過比の特性） （公称降伏応力度を用いた場合）

\begin{tabular}{|c|c|c|c|c|c|c|c|c|c|}
\hline \multicolumn{2}{|c|}{ Classification } & $n$ & $a$ & $\mathrm{~b}$ & $\mathrm{c}$ & d & $\mathrm{m}$ & $\sigma$ & $\sigma / \mathrm{m}$ \\
\hline \multicolumn{2}{|c|}{ All Data } & 237 & -.00 & 1.22 & 0.09 & 1.19 & 1.22 & 0.14 & 0.11 \\
\hline \multirow{6}{*}{$\begin{array}{l}\text { Moment } \\
\text { Gradient }\end{array}$} & D.C. & 18 & 0.14 & 1.27 & 0.59 & 1.16 & 1.33 & 0.10 & 0.08 \\
\hline & U.M. & 33 & 0.38 & 0.98 & -.01 & 1.15 & 1.14 & 0.15 & 0.13 \\
\hline & M.E. & 21 & 0.42 & 1.13 & 0.04 & 1.31 & 1.32 & 0.14 & 0.10 \\
\hline & C.L. & 25 & 0.53 & 1.02 & 0.28 & 1.13 & 1.22 & 0.12 & 0.10 \\
\hline & T.L. & 86 & -.18 & 1.28 & 0.34 & 1.14 & 1.23 & 0.09 & 0.08 \\
\hline & S.S. & 54 & -.66 & 1.43 & 0.25 & 1.06 & 1.16 & 0.14 & 0.12 \\
\hline \multirow{4}{*}{$\begin{array}{c}\text { Width } \\
\text { Thick } \\
\text { Thatioss } \\
\text { Ratio }\end{array}$} & Class $(P-I)$ & 210 & -.03 & 1.24 & 0.08 & 1.20 & 1.23 & 0.14 & 0.11 \\
\hline & Class(P - II) & 5 & 0.05 & 1.20 & 0.10 & 1.19 & 1.23 & 0.01 & 0.01 \\
\hline & Class (P - II) & 3 & -4.0 & 2.14 & 0.13 & 1.05 & 1.11 & 0.02 & 0.02 \\
\hline & Class $(P-I V)$ & 19 & 0.07 & 1.12 & 0.39 & 1.03 & 1.14 & 0.08 & 0.07 \\
\hline
\end{tabular}

上昇によって相殺されたものと推察される。

次に, 実験データを表一4のように降伏比別に分類し， それぞれの分類ごとに超過比を求めた。その結果を表一 6 下段に示す。ここでは, 降伏比ランク II $(0.6 \leqq$ 降伏比 $<0.7)$, III $(0.7 \leqq$ 降伏比 $<0.8)$ の実験データが大半を 占めていた。またランク II III 比較すると, ランク II の超過比が約 $10 \%$ 大きい結果となっている。降伏比が 小さい方がひずみ硬化による耐力の上昇をより見込める ことを勘案すると, この結果も, 予測耐力式がひずみ硬 化による耐力上昇効果を十分に考慮できていないことを 示唆するものである。

3.4 LSD 規準（案）式の耐力予測に対する降伏強さの 影響

鋼材の降伏応力度や最大強度がばらつきの多い量であ ることはよく知られている。そこで鋼材の材料特性が柱 の耐力に及ぼす影響を考察するために, 式（4）の $N_{c r}$ と $M_{c}$ の算定に公称降伏応力度を用いたものを予測耐力 と考え, 超過比を算定したみた。その結果を図一 6 と表 一7に示す。また実験で使用された鋼種とデー夕数の分 類を表一8に示す。全実験データの約 $80 \%$ が, SS 41 を用いた実験から得られたものであった。超過比の平均 値として 1.22 , またその変動係数として 0.11 という結 果を得た。降伏応力度の変動によって, 実験耐力は予測 耐力を更に $7 \%$ 上回った。また無次元化細長比に対す る回帰直線は, 降伏応力度として夷測值を用いた場合が 右上がりの傾向を示していたのに対して, 公称値を用い た場合はほぼ水平となった。また軸力比に対する回帰直 線は，右上がりの傾向となった。実験に用いられた SS 41 について, 実測降伏応力度の公称降伏応力度 $(2.4$ ton $\left./ \mathrm{cm}^{2}\right)$ に対する比を求めた。その結果を図一7に示す。 この比は比較的一様に分布しており, その平均值は 1. 25 であった。

表一8 奏験に用いられた鋼材の種類

\begin{tabular}{|c||c|r|}
\hline Material & $\begin{array}{c}\text { Nominal } \\
\text { Vield Stress } \\
\left(t / \mathrm{cm}^{2}\right)\end{array}$ & $\begin{array}{r}\text { Number } \\
\text { of } \\
\text { Data }\end{array}$ \\
\hline \hline S S 4 1 & 2.4 & 182 \\
\hline SM4 1 & 2.4 & 7 \\
\hline S M 5 0 & 3.3 & 19 \\
\hline H T 6 0 & 4.8 & 5 \\
\hline H T 8 0 & 6.4 & 1 \\
\hline N E S 5 5 & 4.4 & 1 \\
\hline SW H 4 1 & 2.4 & 22 \\
\hline \hline Total & & 237 \\
\hline
\end{tabular}

* NE S 55 : High Strength Steel (in MAKIN001)

* SWH 41 : Light Gaged Steel (in MITANI01) 


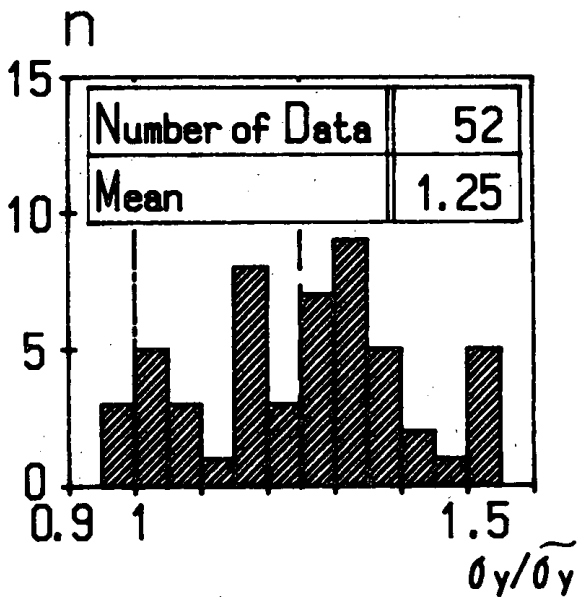

$\widetilde{\sigma}_{y}=$ Nominal Yield Stress

図一7 SS 41 材の降伏応力度の分布

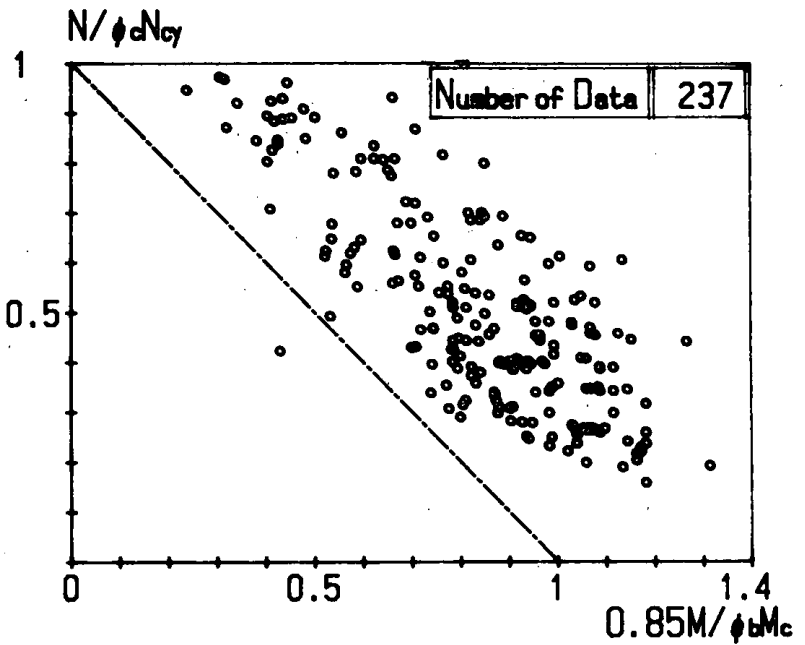

(a)

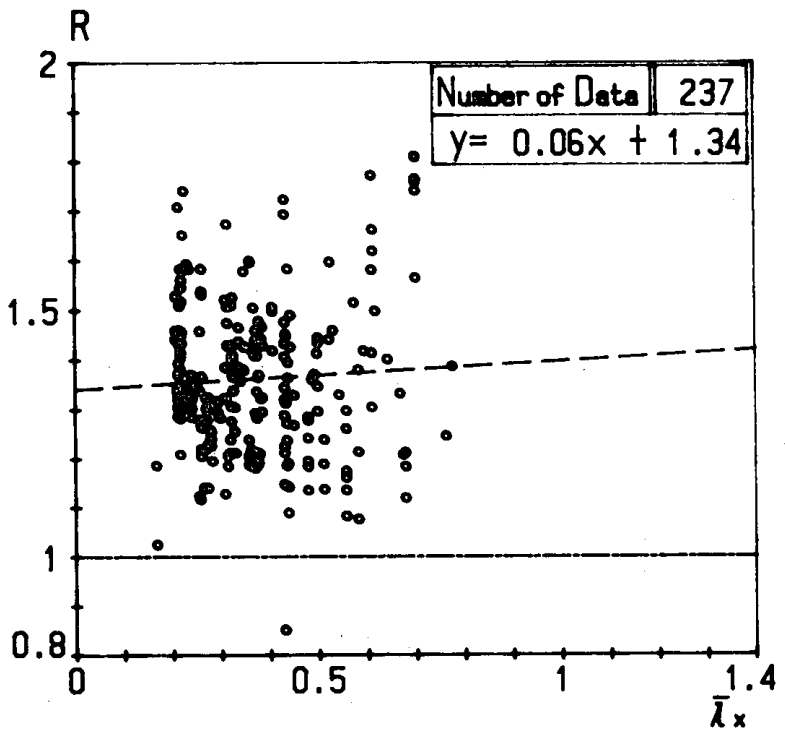

(c)

(a) 軸力と最大曲げモーメントの相関

(c) 超過比亡無次元化細長比の相関
載荷条件ごとにもこの超過比を求めたが，その平均值 が $7 \%$ 程度上がることを除けば, 実測降伏応力度を用 いて求めた超過比とほぼ同じ性状を示していた。ただし， 等モーメントを受ける材の場合だけは, 超過比の平均値 は $2 \%$ しか上昇しなかった。幅厚比ごとに分類してみ ると, ランク I, II のデータが, ランク U, IV のデータ の平均值を $10 \%$ 上回った。

3.5 LSD 規準 (案) 式の設計耐力

式（4）の $N_{C r}$ と $M_{c}$ の算定に公称降伏応力度を用い, さらに，耐力係数 $\left(\phi_{c}, \phi_{b}\right)$ を含めると，この式は LSD 規準 (案) が規定する設計耐力となる。実験耐力と設計 耐力を比較して, その超過比を求めた。その結果を図一 8 と表一 9 に示す。超過比の平均値は 1.36 , またその変

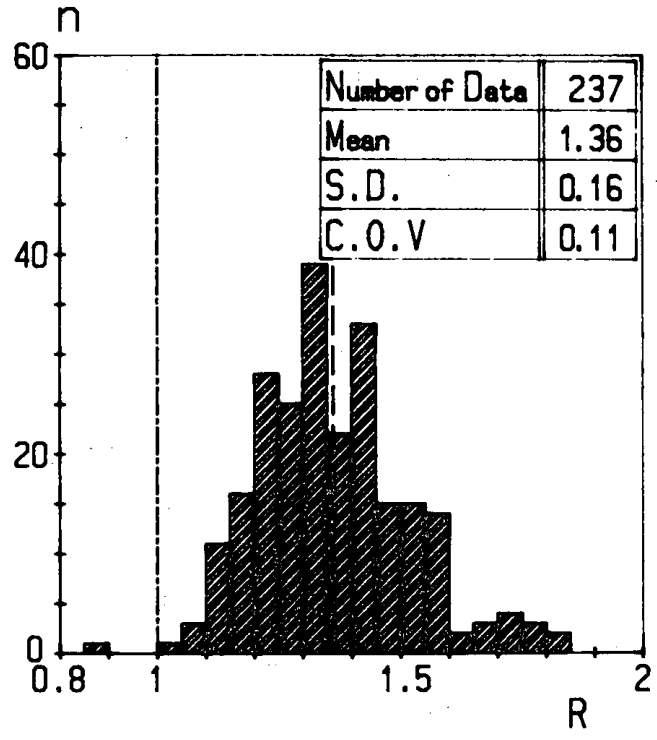

(b)

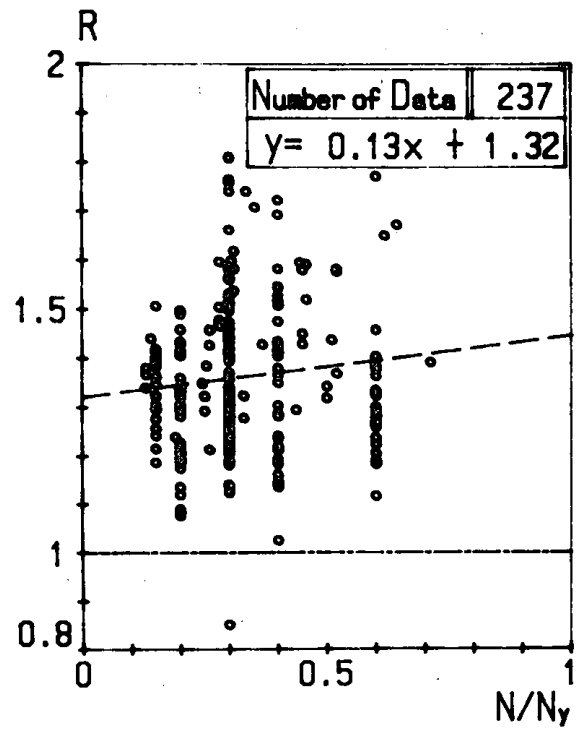

(d)

（b）超過比の頻度分布

（d）超過比亡軸力比の相関

図一8 実験耐力上予測耐力の比較 (公称降伏応力度を用い, 耐力係数を求めた場合) 
動係数は 0.11 であった。これは実験デ一タが設計耐力 を平均で $36 \%$ 上回っているということである。載荷条 件別や幅厚比別の傾向についても，超過比の平均值が上

表-9 実験データの分析結果（超過比の特性）

(公称降伏灾力度を用い耐力係数を含めた場合)

\begin{tabular}{|c|c|c|c|c|c|c|c|c|c|}
\hline \multicolumn{2}{|c|}{ Classification } & $n$ & a & $\mathrm{b}$ & c & d & $\mathrm{m}$ & $\sigma$ & $\sigma / \mathrm{m}$ \\
\hline \multicolumn{2}{|c|}{ All Data } & 237 & 0.06 & 1.34 & 0.13 & 1.32 & 1.36 & 0.16 & 0.11 \\
\hline \multirow{6}{*}{$\begin{array}{l}\text { Moment } \\
\text { Gradient }\end{array}$} & D.C. & 18 & 0.19 & 1.40 & 0.69 & 1.29 & 1.49 & 0.12 & 0.08 \\
\hline & U.M. & 33 & 0.49 & 1.08 & -.04 & 1.31 & 1.30 & 0.18 & 0.14 \\
\hline & M.E. & 21 & 0.55 & 1.24 & 0.02 & 1.49 & 1.49 & 0.16 & 0.11 \\
\hline & C.L. & 25 & 0.64 & 1.12 & 0.30 & 1.27 & 1.36 & 0.14 & 0.10 \\
\hline & T.L. & 86 & -.19 & 1.42 & 0.38 & 1.27 & 1.37 & 0.10 & 0.08 \\
\hline & S.S. & 54 & -.73 & 1.59 & 0.30 & 1.18 & 1.30 & 0.16 & 0.13 \\
\hline \multirow{4}{*}{$\begin{array}{c}\text { Width } \\
\text { Thickness } \\
\text { Ratio }\end{array}$} & Class $(P-I)$ & 210 & 0.02 & 1.36 & 0.11 & 1.33 & 1.37 & 0.16 & 0.12 \\
\hline & Class (P - II ) & 5 & 0.11 & 1.33 & 0.13 & 1.34 & 1.38 & 0.02 & 0.02 \\
\hline & Class (P - III) & 3 & 0.00 & 1.23 & 0.15 & 1.17 & 1.23 & 0.02 & 0.02 \\
\hline & Class ( $\mathrm{P}-\mathrm{IV})$ & 19 & 0.12 & 1.23 & 0.43 & 1.14 & 1.27 & 0.09 & 0.07 \\
\hline
\end{tabular}

昇する以外には，耐力係数を含めない場合の 超過比の特性とほぼ同様の性状を示してい た。

3.6 米国 LRFD 規準の予測耐力と設計耐 力

LRFD 規準における，曲げと軸圧縮力を 受ける材に対する耐力規定（式（5)，(6)） についても，同様の考察を繰り返した。これ らの式において, $P_{n}$ と $M_{n}$ の算定には来测 降伏応力度を用い, さらに耐力係数を省いた ものを予測耐力としたときの超過比を求めた ところ,図一 9 と表一 10 の結果を得た。全デー 夕に対する超過比の平均値は 1.16 となり,
$\mathrm{P} / \mathrm{Pn}[\mathrm{P} / 2 \mathrm{Pn}$ if $\mathrm{P} / \mathrm{Py}<0.2]$

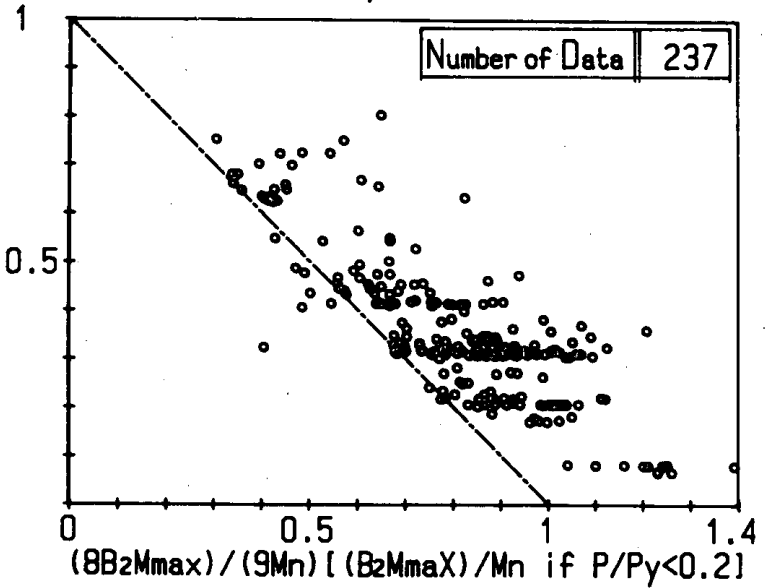

(a)

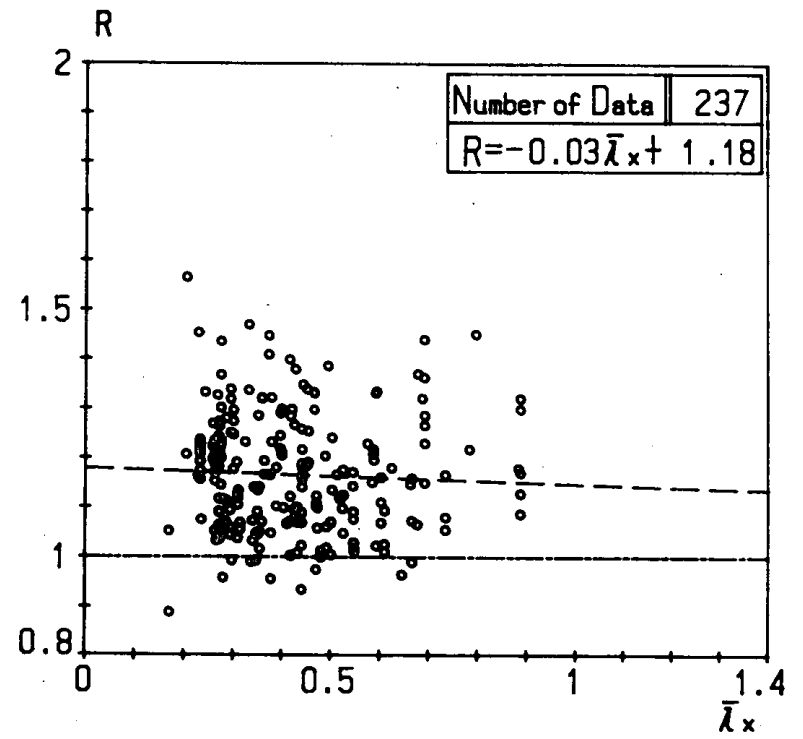

(c)

(a) 軸力と最大曲げモーメントの相関

（c）超過比と無次元化細長比の相関

图一9 実験酎力之予測耐力の比較（LRFD 基準：実測降伏応力度を用いた場合）

（b）超過比の頻度分布

（d）超過比と軸力比の相関

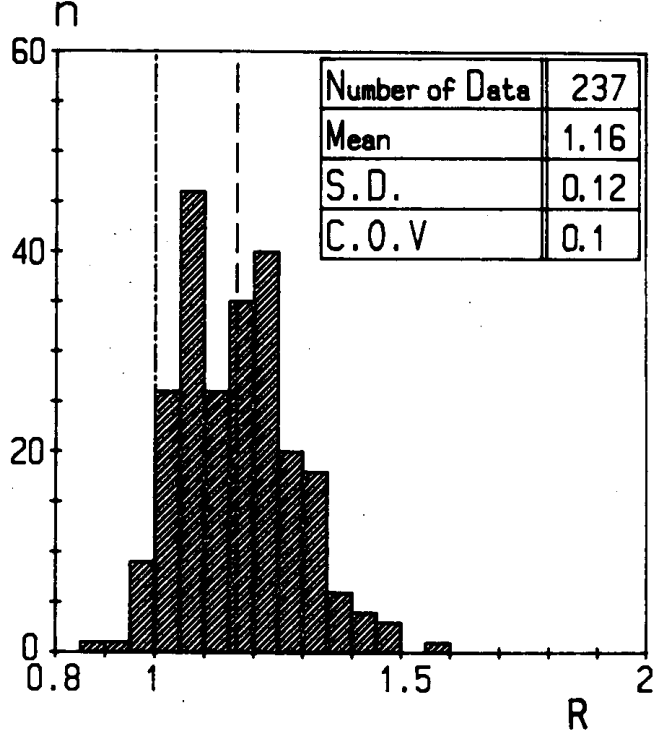

(b)

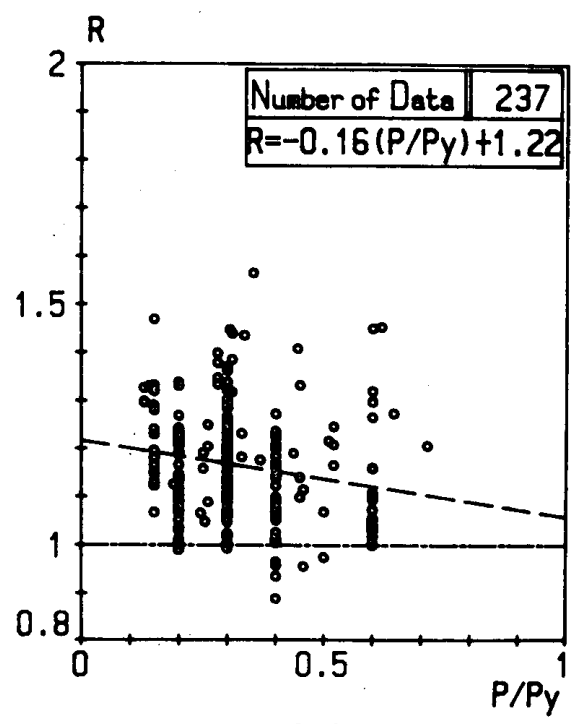

(d)

$\mathrm{R}$ 
表一10 実験データの分析結果（超過比の特性） (LRFD 規準，実測降伏応力度を用いた場合）

\begin{tabular}{|c|c|c|c|c|c|c|c|c|c|}
\hline \multicolumn{2}{|c|}{ Classification } & $\underline{\mathrm{n}}$ & $\mathrm{a}$ & $\mathrm{b}$ & $\mathrm{c}$ & $\mathrm{d}$ & $\mathrm{m}$ & $\sigma$ & $\sigma / \mathrm{m}$ \\
\hline \hline \multicolumn{1}{|c|}{ All Data } & 237 & -.04 & 1.17 & -.16 & 1.21 & 1.16 & 0.12 & 0.11 \\
\hline \multirow{4}{*}{ Moment } & D.C. & 18 & 0.06 & 1.23 & 0.06 & 1.24 & 1.26 & 0.07 & 0.05 \\
\cline { 2 - 10 } Gradient & U.M. & 33 & 0.21 & 0.94 & 0.11 & 1.00 & 1.04 & 0.12 & 0.11 \\
\cline { 2 - 9 } & M.E. & 21 & 0.06 & 1.11 & -.14 & 1.19 & 1.15 & 0.08 & 0.07 \\
\cline { 2 - 9 } & C.L. & 25 & 0.74 & 0.90 & 0.08 & 1.20 & 1.22 & 0.12 & 0.10 \\
\cline { 2 - 9 } & T.L. & 86 & 0.07 & 1.16 & -.22 & 1.24 & 1.18 & 0.09 & 0.07 \\
\cline { 2 - 9 } & S.S. & 54 & -.41 & 1.31 & 0.01 & 1.12 & 1.12 & 0.13 & 0.12 \\
\hline
\end{tabular}

$$
\phi=\exp \left(-\alpha_{\tau} \beta V_{r}\right) \cdot \frac{R_{u m}}{R_{u n}}
$$

で評価してみる (Ravindra and Galambos $(1978)$ )。分離係数 $\left(\alpha_{r}\right)$ として 0.55 を, 安 全性指標 $(\beta)$ として 2.5 , また変動係数 $\left(V_{r}\right)$ と $R_{u m} / R_{u n}$ に本論の分析結果として得られ た 0.11 と 1.22 を代入すると， $\phi$ として 1.05 が得られる。この結果は, 柱に許す設 計曲げ耐力を現行 LSD 規準（案）が定める
LSD 規準（案）を対象としたときの超過比の平均値で ある 1.15 とほとんど変わらなかった。その他, 載荷条 件別等に分類した結果も，若干の相違はあるものの，両 者はおおむ称同じ傾向を示していた。また $P$ と $M$ の算 定に公称降伏応力度を用い，耐力係数を含媓場合の予 測耐力，すなわち設計耐力は，実験耐力を平均で $40 \%$ 上回っているという結果を得たが、これは LSD 規準

(案) 式によった場合の值である $36 \%$ と大差ない。

\section{LSD 規準（案）における柱の曲げ耐力式の評価}

本節では，前節で分析した結果に基づいて，LSD 規 準（案）における柱の曲げ耐力規定の精度を評価する。

(1) 実験耐力は LSD 規準 (案) が規定する予測耐力を 平均で $15 \%$ 上回った。また予測耐力の算定に公称降伏 応力度を用いると，実験耐力は予測耐力を平均で $22 \%$ 上回った。LSD 規準 (案) によると, 構造要素の耐力 $\left(R_{u}\right)$ の平均値 $\left(R_{u m}\right.$ 之定義) の之の公称値 $\left(R_{u n}\right.$ 之定義 $)$ に対する比を 1.10 と定めている。今，柱の曲げ耐力の 公称值を公称降伏応力度を用いた予測耐力之考えると, 本論の分析結果は， $R_{u m}$ の $R_{u n}$ に対する比が 1.22 であ ることを示している。LSD 規準（案）では，柱の曲げ 耐力に対して，この比 $\left(R_{u m} / R_{u n}\right)$ を約 $10 \%$ 低く見積っ ていることになる。

(2) $R_{u m}$ と $R_{u n}$ の違い $(22 \%)$ を，予測耐力式が持つ 予測誤差と,鋼材のばらつきによる変動の和と考えると, その内訳は予測誤差によるものが $15 \%$ ，鋼材のばらつ きによるものが $7 \%$ である。 $R_{u m}$ と $R_{u n}$ の違いは， LSD 規準（案）が規定している予測耐力に対する予測 誤差により多く依存している。

(3) 本論での実験耐力と予測酎力の比の分析結果による と, 変動係数は 0.11 という結果を得た。一方, LSD 規 準 (案) では $R_{u m} / R_{u n}$ の変動係数を $0.15 \sim 0.20$ に設定 している。本論で取り扱ったのが，構造実験のために精 度良く製作された単体試験体であったのに対し，現実の 部材は現場で骨組に組み立てられることを考えると， LSD 規準（案）が想定している変動係数はおおむね納 得できる值と考えられる。

(4) 実験耐力は設計耐力を $36 \%$ 上回るという結果を得 た。今 2 次モーメント法に従って, 耐力係数 $\phi$ を次式
設計耐力の 1.17 倍 $(=1.05 / 0.9$ :ここで 0.9 を LSD 規準（案）の耐力係数とした）にしても，なおこの規準 (案) が考えている安全性を確保することは可能である ことを示唆している。

(5)このように現行の設計耐力は安全側に位置している が, その理由の一つとして,ひずみ硬化の影響が考えら れる。前節までに述べたように，柱の曲げ耐力を規定す る式の中には, 柱の一部が軸力を考慮した全塑性モ一メ ントを越えて抵抗してゆく可能性が基本的には考慮され ていない。一方本論の分析の結果から，モーメント勾配 のある材や降伏比の小さい材に対する実験デー夕の方 が, 実験耐力の予測耐力に対する比 (超過比) が大きかっ た。本論で分析した範囲では, モーメント勾配の有無や 降伏比の大小に応じて，おおむね 10１5％程度の超過 比の変動が観察された。柱の曲げ耐力評価式 (式 $(4))$ の中にひずみ硬化の影響を取り込むことによって，その 予測精度は向上できると考えられる。ただし本論で分析 した材の大多数は, 細長比の比較的短い材（強軸回りの 無次元化細長比にして 0.5 以下) であったことは留意し なければならない。

(6) $P \Delta$ 効果が含まれるサイドスウェイを伴う材の超過 比が，これを含まない逆対称モーメントや一端モーメン 卜を受ける材の超過比を $15 \%$ 程度下回ったが，これは， 本分析において，PA効果による付加曲げモーメントを 加えずに最大曲げモーメントを算出したことが原因の一 つである。しかし，上にも述べたように，式（4）はか なり安全側なものとなっているため，PD効果による付 加曲げモーメントを無視しても,なお安全側の值を与え ている。

(7) 上の考案から, 現行 LSD 規準 (案) が規定する柱 の曲げ設計耐力はおおおよそ $15 \%$ 安全側に位置すること が明らかになったが，この $15 \%$ の違いを大きいと見る か小さいと見るかは，他の構造部材に対する耐力予測精 度や, また各構造部材の性能の構造物全体の性能に対す る貢献度等を考慮しながら相対的に論議すべきものであ る。筆者らはこれらの精度や貢献度を定量化してゆく研 究こそが先決であると考え, 本論をもって, 曲げと軸圧 縮力を同時に受ける材の耐力に関する規定を，直ちに修 正すべきであるという立場を採るものではない。 


\section{5. まとめ}

鉄骨柱材に対する実験データをデータベース化し，そ れを分析することによって，鉄骨柱材の梸力特性を考察 し，また LSD 規準（案）が定める柱材の設計耐力式を 評価した。主な知見を以下にまとめる。

(1) 実験耐力は, LSD 規準（案）が想定する予測耐力

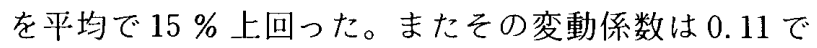
あった。

(2) 予测耐力の算定に公称降伏応力度を用いると, 実験 耐力は予测耐力を平均で $22 \%$ 上回った。変動係数は 0.11 と変わらなかった。

(3) LSD 規準（案）の設計耐力は実験耐力を平均で 36 $\%$ 上回る結果となった。また 2 次モーメント法によっ て試算したところ，現行 LSD 規準（案）における柱の 設計耐力を 1.17 倍にしても，なおこの規準が要求して いる安全性を確保することが可能であるという結果を得 た。

(4) 柱の曲げ耐力に及ぼすひずみ硬化の影響が少なくな いこととが (本論で分析した範囲では，10１5％耐力 を変動させる), 降伏比やモーメント勾配の違いによる 実験耐力と予測耐力の比の変動から明らかになった。

\section{参考文献}

1) 宇田川邦明, 高梨晃一, 田中 尚 (1974)：繰り返し載荷 を受ける鋼製柱の曲げ捩れ崩壊, 日本建築学会大会学術 講演梗概集 (北陸)，pp.923-924，昭和 49 年 10 月.

2) 加藤 勉, 秋山 宏, 山崎真司 (1974)：H形断面材の塑 性曲げ㨭れ座屈実験, 日本建築学会論文報告集, 第 222 号, pp. 11-21, 昭和 49 年 8 月.

3）加藤 勉, 秋山 宏, 帯 洋一 (1977) : 局部座屈を伴う H 形断面部材の変形, 日本建築学会論文報告集, 第 257 号, pp. 49-58, 昭和 52 年 7 月.

4) 鋼構造限界状態設計規準 (案) - 同解説 (LSD 規準 (案)), 日本建築学会, 1990.

5）鈴木敏郎，小野徹郎（1971）：柱の補剛に関する実験的研 究, 日本建築学会論文報告集, 第 188 号, pp. 33-40, 昭 和 46 年 10 月.

6）鈴木敏郎，玉松健一郎（1979）：低層鉄骨骨組柱材の工六 ルギ一吸収能力に関する実験的研究（その1. 単調載荷お よび低変位振幅載荷を受ける H 形鋼柱材のエネルギー吸 収能力), 日本建築学会論文報告集, 第 279 号, pp. 65-75, 昭和 54 年 5 月。

7）鈴木敏郎，小野徹郎（1980）：圧縮と曲げを受ける鉄骨 H 形断面柱の塑性変形能力に関する研究 (その 1), 日本建 築学会論文報告集, 第 292 号, pp. 23-29, 昭和 55 年 6 月.

8）鈴木敏郎, 酒井新吉, 貫井 泰 (1980)：局部座屈を伴う $\mathrm{H}$ 形鎆柱部材の変形能力, 日本建築学会大会学術講演梗 概集（近畿），pp. 1151-1152，昭和 55 年 9 月。

9）鈴木敏郎, 酒井新吉 (1981)：座屈を伴う H 形鋼柱部材の 繰り返し荷重下におりる変形性状, 日本建築学会大会学 術講演梗概集 (九州), pp. 2063-2064, 昭和 56 年 9 月.
10）高梨晃一ほか（1976）：軸力と繰り返し曲げをうけるH形 鋼柱の変形能力, 日本建築学会大会学術講演梗概集 (東 海), pp. 1081-1082, 昭和 51 年 10 月.

11) Nakashima, M., Nakamura, T., and Wakabayashi, M. (1983) : Post-buckling Instability of Steel Beam-columns, Journal of Structural Engineering, ASCE, Vol.109, No.6, June, pp.1414-1430, 1983.

12) Nakashima, M., Takanashi, K., and Kato, H. (1990): Test of Steel Beam-columns Subject to Sidesway, Journal of Structural Engineering, ASCE, Vol.116, No. 9, September, pp. 2516-2531, 1990.

13）福地保長, 小倉正憲, 尾崎猛美（1976）：H形鋼柱のフラ ンジ局部座屈と履歴性状に関する研究，日本建築学会大 会学術講演梗概集（東海)，pp. 1087-1088，昭和 51 年 10 月.

14）福地保長，尾崎猛美，笠木 薫 (1977)：H形鋼柱のフラ ンジ局部座屈と履歴性状に関する研究（その2. 漸増変位 繰り返し載荷について)，日本建築学会大会学術講演梗概 集 (中国), pp. 1349-1350, 昭和 52 年 10 月.

15）福地保長, 尾崎猛美, 笠木 薰 (1977)：H形鋼柱のフラ ンジ局部座屈と履歴性状に関する研究（その3. 初回に大 変形を受ける場合), 日本建築学会大会学術講演梗概集 (中 国)，pp. 1351-1352，昭和 52 年 10 月.

16）福地保長, 笠木 董, 尾崎猛美 (1978)：H形鋼柱のフラ ンジ局部座屈と履歴性状に関する研究（その $4 . b / t=10$ の柱の塑性変形振幅と耐力低下について), 日本建築学会 大会学術講演梗概集 (北海道), pp. 1313-1314, 昭和 53 年 9 月.

17）福地保長, 笠木 薰 (1980)：H形鋼柱のフランジ局部座 屈之履歷性状に関する研究（その 5. 定変位振幅実験とラ ンダム変位振幅実験での履歴性状), 日本建築学会大会学 術講演梗概集（近畿），pp. 1163-1164，昭和 55 年 9 月.

18）牧野 稔, 松井千秋, 三谷 勲 (1979)：H形鋼柱の局部 座屈後の変形性状 (その1. 実験計画および実験結果), 日本建築学会論文報告集, 第 281 号, pp. 71-80, 昭和 54 年 7 月.

19）牧野 稔, 松井干秋, 三谷 勲 (1979)：H形鋼柱の局部 座屈後の変形性状 (その2. 荷重-変形関係), 日本建築学 会論文報告集，第 286 号, pp. 23-28, 昭和 54 年 12 月.

20) 三谷 勲ほか (1986)：複曲率曲げを受ける H 形鋼柱の塑 性変形能力に及ぼす軸力比および曲げモーメント比の影 響, 日本建築学会構造系論文報告集, 第 370 号, pp. 69-80, 昭和 61 年 12 月.

21) "Load \& Resistance Factor Design", Specification for Structural Steel Buildings, American Institute for Steel Construction, USA, 1986.

22) Ravindra, M. K. and Galambos, T. V. (1978), "Load and Resistance Factor Design for Steel", Journal of the Structural Division, ASCE, Vol. 104, pp. 1337-1353, No. ST9.

23）若林 実, 岡本晴仁, 小柳博義 (1972)：H形鋼柱の非弾 性座屈に関する研究, 日本建築学会大会学術講演梗概集 (九州), pp. 1353-1354, 昭和 47 年 10 月.

(1990 年 4 月 10 日原稿受理・1990 年 9 月 20 日採用決定) 